\title{
In-Class versus Out-of-Class Flipped Classroom Models in English as a Foreign Language Writing
}

\section{Modelos de aula invertida dentro del aula versus fuera de clase en la escritura en inglés como lengua extranjera}

\author{
Fatma SENGUL \\ Department of English Language Teaching, Near East University, Near East Boulevard, PK: \\ 99138, North Cyprus, Mersin 10 Turkey \\ Hanife BENSEN BOSTANCI \\ Department of English Language Teaching, Near East University, Near East Boulevard, PK: \\ 99138, North Cyprus, Mersin 10 Turkey
}




\section{Summary}

A flipped classroom model is an indispensable part of the English as a foreign language (EFL) writing courses as it helps the instructor to advance the learners' writing proficiency levels (Pavanelli, 2018). However, EFL students' attitudes toward the in-class and out-of-class writing models in a flipped classroom process are unknown. Understanding these issues have a vital importance as these will help educators arrange their writing classes based on the flipped classroom models in order to have an effective writing course in line with EFL students' needs (Abaeian \& Samadi, 2016). Therefore, this study purposed to investigate the EFL students' attitudes toward in-class and out-of-class writing models in a flipped classroom. A quantitative research design was employed through the use of a questionnaire which was employed to $30 \mathrm{EFL}$ students studying at a private university's English language teaching department. As the findings showed, although the EFL students had positive attitudes towards both flipped classroom models for writing, they preferred the out-of-class model and the majority of them stated that they prefer to produce their written work out-of-class settings. As a consequence of these, EFL educators should use an out-of-class flipped classroom model for writing, if they give priority to their EFL students' attitudes towards the writing models on account of having an effective writing course.

Keywords: flipped classroom, in-class writing, out-of-class writing, English as a foreign language learners, writing, perceptions, preferences.

\section{Resumen}

Un modelo de aula invertida es una parte indispensable de los cursos de escritura de inglés como lengua extranjera (EFL), ya que ayuda al instructor a avanzar en los niveles de competencia en escritura de los alumnos (Pavanelli, 2018). Sin embargo, se desconocen las actitudes de los estudiantes de EFL hacia los modelos de escritura dentro y fuera de clase en un proceso de aula invertida. Comprender estos temas tiene una importancia vital, ya que ayudarán a los educadores a organizar sus clases de escritura en función de los modelos de aula invertida para tener un curso de escritura efectivo en línea con las necesidades de los estudiantes de inglés como lengua extranjera (Abaeian y Samadi, 2016). Por lo tanto, este estudio se propuso investigar las actitudes de los estudiantes de inglés como lengua extranjera hacia los modelos de escritura en clase y fuera de ella en un aula invertida. Se empleó un diseño de investigación cuantitativa mediante el uso de un cuestionario que se aplicó a 30 estudiantes de inglés como lengua extranjera que estudiaban en el departamento de enseñanza del idioma inglés de una universidad privada. Como mostraron los hallazgos, aunque los estudiantes de inglés como lengua extranjera tenían actitudes positivas hacia ambos modelos de aula invertida para la escritura, prefirieron el modelo fuera de clase y la mayoría de ellos declaró que prefieren producir su trabajo escrito fuera de clase. Como consecuencia de esto, los educadores de EFL deben usar un modelo de aula invertida fuera de clase para la escritura, si dan prioridad a las actitudes de sus estudiantes de EFL hacia los modelos de escritura debido a que tienen un curso de escritura efectivo.

Palabras clave: aula invertida, escritura en clase, escritura fuera de clase, estudiantes de inglés como lengua extranjera, escritura, percepciones, preferencias.

\section{Introduction}

Currently, there has been an advancing but constant modification in how the instructional process is achieved in English as a foreign language (EFL) classes (Abaeian \& Samadi, 2016). Accordingly, the instructional process in EFL contexts have been putting emphasis on the productive skills especially, the writing and speaking skills of the EFL students (Ahmed, 2016). In particular, writing is mentioned as the most essential part of all courses such as, History, Science, and foreign language learning which is regarded as one of the most influential skills that is used for communicative purposes in the globalised world (Ekmekçi, 2017). Nowadays, EFL 
students have an inadequate performance in the writing process in the Turkish Cyprus context (Agustina \& Nur, 2018; Dimililer \& Kurt, 2019). Although writing is announced as the most essential piece of the courses, it is not easy to teach writing in the EFL Turkish Cypriot contexts as it is challenging to plan, produce, arrange, and deliver the thoughts through expressive messages (Al-Shaer, 2014; Dimililer \& Kurt, 2019; Febrijanto, 2016; Koura \& Zahran, 2017; Suyanto, 2015).

Flipping the classroom is regarded as one of the promising approaches to transform instructional practices with a holistic integration of the online platforms and responsive instructional methods (Hung, 2015). The major idea behind this innovative approach is to adverse the course order through moving traditional course out of the class environment by requesting the students to review the course materials and perform the necessary tasks that introduce the subject matter of the course before participating into the class (Alastuey \& Galar, 2017). Accordingly, course time can be arranged more sufficiently and effectively for the writing courses (Ekmekçi, 2017). Importantly, there are numerous ways to flip the traditional classroom environment consequently, only one technique cannot be used for all circumstances (Abeysekeraa \& Dawson, 2015; Helgeson, 2015;). For instance, some of the EFL instructors ask the students to produce their written works in the classroom, while some of them ask the students to produce their written works out of the classroom settings, and even though these flipped classroom models are commonly used by educators, there still seems to be a gap about the mostly preferred flipped classroom model and EFL students' perceptions towards the in-class and out-of-class flipped classroom writing models (Hsiao, Huang, Huang, Lu, Yin \& Yang, 2018), specifically in the Turkish Cypriot context.

To be able to reveal the aforementioned issue, the following research questions are asked as a part of the investigation:

1) Which flipped classroom model is mostly preferred by the English as a foreign language students in the writing process?

2) What are the English as a foreign language students' perceptions towards the in-class versus out-of-class flipped classroom models in the writing process?

\section{Literature Review}

Writing in the EFL context is regarded as one of the most influential skill which is used for communicative purposes in a globalised world this is why, in order to enable learners to attain an adequate competency level educators are needed to place great emphasis on it (Ekmekçi, 2017). In addition to this, in educational environments, writing is the basis where the learners' achievement, advancement, progress and knowledge are assessed (Ghalib \& Al-Hattami, 2015). As Saed and Al-Omari add on that "it is a comprehensive skill that helps reinforce vocabulary, grammar, thinking, planning, editing, revising, and other elements" (p. 88). For these reasons, writing is considered as a difficult process in EFL teaching and learning (Ningrum, Latief \& Sulistyo, 2016). Therefore, advancing the learners' writing abilities is believed to be one of the necessary part of EFL learning process (Ibnian, 2010).

Notwithstanding, there are so many challenges in EFL writing classes, especially in the Turkish Cypriot context (Afrilyasanti, Cahyono \& Astuti, 2016; Dimililer \& Kurt, 2019; Koura \& Zahran, 2017). These challenges are believed to exist as a consequence of the instructional process, where the lecturers apply inappropriate traditional instructional approaches, methods, techniques and models to teach writing (Koura \& Zahran, 2017). For these reasons, institutes, educators, researchers and so on began to investigate recent techniques to boost the EFL learners' language proficiency levels (Hinrichs, 2011). Following these, numerous investigators have examined the instructional approaches, methods, models and so on that might be effective to advance the EFL learners' writing proficiency (Ningrum, Latief \& Sulistyo, 2016). Significantly, the majority of the traditional approaches for writing are outdated and do not take into consideration the learners' higher order thinking abilities in the Turkish Cypriot context (Dimililer \& Kurt, 2019). As it is agreed that the traditional instructional approaches are not influential and effective at all, the key of success is the innovation of educational approaches, methods, models and so on (Wang \& Liu, 2018). Due to these reasons, instructional trends in EFL classes have repeatedly been focalizing on the writing skills of the learners for the purpose of shifting away the traditional instructional 
processes to the technology based innovative ones in the Turkish Cypriot context (Ahmed, 2016; Ahmed \& Asiksoy, 2018). Thus, there has been a request for the more recent approaches, such as the flipped classroom approach that combines both the in-class instructional process with the online instructional environments in EFL writing classes (Ügüten \& Balc1, 2017).

Flipped classroom is commonly used to describe the learning activities, where the learners are taught the course content through several technology oriented materials before coming to the class, instead of presenting the course content during the class time as in the traditional lectures (Adnan, 2017). Generally, the learners "with diverging, assimilating, converging, and accommodating learning style taught using flipped classroom model achieved better ability in writing than those learning in a traditional classroom" (Afrilyasanti, Cahyono \& Astuti, 2016, p. 68). Significantly, as it is emphasized by many researchers, the flipped classroom approach has become an increasing technological development which is also defined as the innovative pedagogical approach of the EFL education in the Turkish Cypriot context (Ahmed \& Asiksoy, 2018). As the reviewed research findings indicated, flipped classroom models enable the learners to engage in more technology based instruction, actively participate in the lesson, and it also responds to their needs through the implementation of more communicative, creative, problem solving and critical thinking activities both inside the classroom and outside the classroom (Ahmed, 2016; Alsowat, 2016). On top of these, researches found out that the flipped classroom based courses are a little bit challenging to prepare, but very effective for allowing the learners to be more autonomous in the language learning process, as the information construction process is based on the dynamic participation of the learners (Ügüten \& Balc1, 2017). In addition to these, several research findings pinpointed that the flipped learning models motivates learners and increases their preparation and participation in the lesson (Chen, Liou \& Chen, 2018; Fraga \& Harmon, 2014). Further, it is also found that by the help of the flipped classroom approach the EFL learners have more chances to receive individual, peer and instructor feedback (Ekmekçi, 2017). Following these, it is also stated that the flipped classroom based writing classes enable the instructors to advance their course objectives through the use of technology (Aidinlou, Sharefii \& Kordabadi, 2017). Likewise, it is emphasized that the numerous EFL learners had positive perceptions towards the flipped classroom approach during their writing courses as it allowed them to be at the centre of their knowledge construction process (Fraga \& Harmon, 2014). In the same way, investigators also agreed that the flipped classroom approach increases the learners' writing performances and their engagement into the lesson consequently, both the EFL learners and instructors had strongly positive perceptions towards this approach (Alastuey \& Galar, 2017). Another research's findings emphasized that both the EFL learners and instructors agreed that during the instructional process each individual had their own pace of learning and flipped classroom models had provided opportunities to them to become aware of their learning needs and styles (Ekmekçi, 2017). Overall, flipped classroom approach is a promising, engaging, innovative, needs and technology based instructional approach that enables the instructors to arrange the courses in line with the learner needs through transforming the traditional lecture based courses to the technology oriented online instructional environments without any time limits (Güvenç, 2018). To summarize, flipped classroom environments are proved to affect the learner performance in a positive way during the writing process, and also supply more independent, personalized learning as well as, more flexibility in learning time (Fraga \& Harmon, 2014). Specifically, there are different models of the flipped classroom approach for the writing courses that the EFL instructors can use in order to advance their writing courses (Helgeson, 2015). The selection of the convenient writing model is important as the choice of the appropriate writing model is important as it helps the writer to achieve his/her objectives and produce more effective, influential and persuasive written works (Carroll, 2013; Site, 2018). Particularly, flipped classroom models in the writing process can be categorized in line with the use of in-class and out-of-class time and environments (Panopto, 2017; Thakare, 2018). Initially, the term writing model can be defined as the writing process where the learners are asked to produce their written texts, in-class or out-of-class environment based on the flipped classroom approach and the in-class writing model can be identified as the writing process where the learners produce their written texts in the classroom environment, on account of making the writing process more effective, productive and persuasive, while the out-of-class writing model can be defined as the 
writing process where the learners produce their written texts out of the classroom environment in order to make their writing more influential, efficient and convincing (Carroll, 2013; Chang, 2016; Qader \& Arslan, 2019; Zou \& Xie, 2018). In short, flipped classroom models in the writing process can be categorised as in-class and out-of-class writing models (Thakare, 2018). To put it simply, in-class writing model is based on the flipped classroom approach, stresses the significance of the instructors' guidance and support and in that writing model, the learners complete the online pre-course activities before coming to the classroom, while during the classroom hour the learners are asked to complete several tasks before producing their written works in the classroom settings, whereas out-of-class writing model put emphasis on the importance of producing written works out of the classroom environment after the completion of several tasks in the classroom environment as similar to the in-class writing model (Panopto, 2017; Thakare, 2018). As a matter of the fact that flipped classroom model might vary depending on the course objectives, there might be effect of the use of different flipped classroom models on the EFL learner's academic achievement and also their perceptions and preferences towards these two flipped classroom models (Afrilyasanti, Cahyono \& Astuti, 2016). In fact, it is very important to take into consideration about the EFL learners' perceptions and preferences towards these two flipped classroom models for writing in the Turkish Cypriot context as some of the learners might find it challenging to write out-of-class environment as there is no instructors' guidance or vice versa of it, and another perception might about the time limitation as there is a limited time for writing in the in-class writing model whereas, out-of-class model enables unlimited time for writing (Afrilyasanti, Cahyono, \& Astuti, 2016; Ahmed, 2016; Chang, 2016; Salem, 2010; Lin \& Hwang, 2018). Regarding the stated issues, numerous EFL learners in general and also in Turkish Cypriot context face with challenges, problems and failures in the writing process and in order to overcome these issues, EFL learners should be asked for their preferences and perceptions towards the flipped classroom model that they would like to be taught and the instructors should rearrange their courses in line with the perceptions and preferences of the EFL learners (Fraga \& Harmon, 2014; Helgeson, 2015; Lin \& Hwang, 2018). Importantly, as the flipped classroom approach are still relatively recent in the EFL writing contexts and also Turkish Cypriot context, there is no scientific study has been done on flipped classroom models in EFL writing classes (Ahmed \& Asiksoy, 2018; Chang, 2016). As a result, there is a demand to examine the impacts of flipped classroom models on the EFL learners' target language performances and language skills in order to find out the most appropriate teaching and learning models for the successful implementation of the flipped learning model in the EFL writing courses (Abaeian \& Samadi, 2016). Remarkably, until now, no investigation has been administered in the EFL context examining the efficacy of implementing flipped classroom models in EFL writing contexts as well as Turkish Cypriot context (Alnuhayt, 2018). In particular, this kind of study will help the instructors to design and have a more fruitful and effective flipped classroom based writing course (Abaeian \& Samadi, 2016). For these reasons, there is a need for the studies that will investigate about the efficiency of the flipped classroom models in the EFL contexts in general, as well as in Turkish Cypriot context and the EFL learners' perceptions and preferences towards them (Afrilyasanti, Cahyono \& Astuti, 2016).

\section{Methodology}

\section{Research Design and Procedures}

A survey research design was chosen as the design of the research. Survey research design is a kind of research design where the questionnaires are implemented to the selected sample of participants from population on account of reaching to the quantitative data about the particular subject (Odoh \& Chinedum, 2014). In fact, through the use of a questionnaire as its data collection tools, the study collected quantitative data from the participants who were chosen from the population that were conveniently available to participate in the investigation. Through the analysis of quantitative data, the investigator purposed to transform the data into numerical form (Green, 2015).

First and foremost, a questionnaire was administered to the EFL learners, on account of comprehending their perceptions and preferences towards the use of in-class and out-of-class 
writing models in their flipped writing classes (see Appendix C and D). Significantly, the participants of the two different classes filled in a different version of the same questionnaire. In other words, participants in group A filled in a questionnaire about an in-class flipped classroom model for writing, while participants in group B filled in a questionnaire about an out-of-class flipped classroom model for writing.

The questionnaire data were gathered during the 2019-2020 fall semester, from the $30 \mathrm{EFL}$ students in two different writing classes from the English language teaching department of a private university in North Cyprus.

\section{Participants and Sampling}

This study employed convenience sampling as it was purposed to gather the particular type of information from EFL students and instructors that were conveniently accessible to take part in the research. Convenience sampling can be characterized as a kind of "nonprobability sampling, where the members of the target population that meet certain practical criteria, such as easy accessibility, geographical proximity, availability at a given time, or the willingness to participate" (Etikan, Musa \& Alkassim, 2016, p. 2).

Fifteen of the students in group A and 15 students in group B, in total 30 participants constituted the participants of this study.

\section{Data Collection and Analysis}

To be able to reveal the aforementioned research questions data were collected quantitatively from the researcher-made questionnaire, where the participants' statements about the EFL students' perceptions and preferences towards the flipped classroom writing models were stated. The participants were asked to rate statements appropriately on a five-point Likert scale, indicating their degree agreement. Firstly, in Section A, the students were asked to put the statements about the in-class vs out-of-class flipped classroom models in EFL writing classes in order of importance, while in Section B they were requested to rate their perceptions towards the in-class and out-of-class writing models in the flipped classroom, in line with their level of agreement. Lastly, in Section C, they were asked to rate their preferences and perceptions towards the in-class and out-of-class flipped classroom writing models with respect to their level of agreement.

The data which were collected from the questionnaire were analysed quantitatively. Significantly, SPSS software version 20. was employed. Descriptive statistics was used to examine the questionnaire data. Later, various histograms were used to show the distribution of the data.

\section{Validity and Reliability}

The questionnaire was adopted and adapted from Şengül's (2018) questionnaire which was used to examine EFL learners' perceptions and preferences towards the agent factor during the indirect written feedback process in her MA thesis. The findings of the questionnaire were examined through Cronbach's alpha, in order to find out whether the statements are reliable or not. Accordingly it was found that the co-efficiency was 0.80 which means that the questionnaire was reliable as "many methodologists recommend a minimum $\alpha \alpha$ coefficient between 0.65 and 0.8 (or higher in many cases); $\alpha \alpha$ coefficients that are less than 0.5 are usually unacceptable" (Virginia, 2015, p. 1).

Prior to conducting this research, a consent form was created. All necessary documents were prepared and all necessary forms were filled in. Then, the researchers applied to the Ethics Committee of the Institute of Education Sciences of Near East University, in order to acquire a scientific investigation etiquette. Following these, all the necessary documents such as ethical approval acceptance letter and the informed consent form were shared with the participants of the investigation. Equally important, the participants were also informed that the data collected from this investigation will be kept confidential and will not be shared or accessed for any objective except for analysis.

\section{Findings and Discussion}

\section{Flipped Classroom Model Preferences}


On account of finding an answer to the first research question which was about the EFL students' flipped classroom model preferences, in the primary part of the questionnaire, the participants were asked about their in-class and out-of-class writing preferences during the flipped classroom writing process. The results pinpointed that a great number of participants in group A preferred both in-class and out-of-class writing (M: 1.93, SD: 0.79), whereas the majority of the participants in group B preferred out-of-class writing (M: 1.87, SD: 0.64) during the flipped classroom writing process (see Table 1). In line with the findings of this research, in Ekmekçi's (2017) study when the participants were asked about their preferences among flipped classroom models, the majority of the participants preferred to write out-of-the class environment, which was believed as the untraditional method of flipped classroom model for writing.

Advantages and Disadvantages. Moreover, in the first part of the questionnaire, the participants were also asked about their perceptions towards the flipped classroom models for writing regarding whether in-class and out-of-class writing processes have advantages and/or disadvantages during the flipped classroom writing process. The findings indicated that more than half of the participants in group A agreed that in-class writing has both advantages and disadvantages (M: 2.27, SD: 0.96), and the majority of the participants in group B agreed that out-of-class writing has both advantages and disadvantages (M: 2.27, SD: 1.10) during the flipped classroom writing process (see Table 1). Dissimilar with the findings of the research, in their study Akçayır, G. \& Akçayır, M. (2018) found that out-of-class writing had more disadvantages than advantages.

The Best Source. Besides, in order to reach more information about the EFL students' perceptions towards the flipped classroom models, in the initial part of the questionnaire the participants were asked about the best source to get help from during the flipped classroom based in-class and out-of-class writing process. According to the findings, more than half of the participants in group A agreed that the best source to get help during the in-class writing process was the instructor (M: 2.40, SD: 1.63), while a great number of the participants in group B agreed that the best source to get help during the in-class writing process is online sources (M: 3.47, SD: 1.80) (see Table 1). Overall, it was found that the best source to get help during the in-class writing process was the instructor, while the best source to get help during the out-of-class writing process was online sources, and these results are partially in-line and opposite to the findings of Santosa (2017) who found that, although the EFL learners in flipped classroom settings use several sources to get help from during the writing process, they are in favour of the instructor as the first and best source to get help for in writing classes.

Table 1. EFL Learners' Perceptions

\begin{tabular}{|c|c|c|c|c|}
\hline Statements & \multicolumn{2}{|c|}{ In-Class W } & \multicolumn{2}{|c|}{ Out-of-Class W } \\
\hline & $\mathrm{M}$ & SD & $\mathrm{M}$ & SD \\
\hline 1. If I had another chance to be & & 070 & 187 & 064 \\
\hline $\begin{array}{l}\text { taught writing, I prefer to write } \ldots \\
2 . \quad \text { I think writing } \\
2 .\end{array}$ & 1.93 & 0.19 & 1.81 & 0.64 \\
\hline $\begin{array}{l}\text { environment has advantages and/or } 15 \\
\text { disadvantages. }\end{array}$ & 2.27 & 0.96 & 2.27 & 1.10 \\
\hline $\begin{array}{l}\text { 3. The best source to receive } 15 \\
\text { help, while writing is ... }\end{array}$ & 2.40 & 1.63 & 3.47 & 1.80 \\
\hline Valid N (listwise) & & & & \\
\hline
\end{tabular}

Key: M: Mean Score SD: Standard Deviation W: Writing N: Number

Feelings. In order to find out more detailed information about the EFL learners' perceptions towards the flipped classroom models for writing, the participants were asked about their feelings towards the in-class versus out-of-class flipped classroom models, the majority of the participants in group A agreed that, when they write in-class they feel more knowledgeable (M: 3.47, SD: 
(M: 3.27, SD: 1.48), confident (M: 3.27, SD: 1.43), and shy (M: 1.20, SD: 0.41); less excited (M: 3.07, SD: 1.53), energetic (M: 2.87, SD: 1.59), comfortable (M: 2.87, SD: 1.55), thoughtful (M: 2.87, SD: 1.40), relaxed (M: 2.73, SD: 1.58), confused (M: 2.67, SD: 1.54), determined (M: 2.67, SD: 1.34), amused (M: 2.60, SD: 1.63), sleepy (M: 2.53, SD: 1.64), nervous (M: 2.53, SD: 1.30), bored (M: 2.40, SD: 1.45), anxious (M: 2.33, SD: 1.34), tired (M: 2.27, SD: 1.66), stressed (M: 2.27, SD: 1.33), puzzled (M: 2.20, SD: 1.47), indifferent (M: 2.20, SD: 1.26), humiliated (M: 2.13, SD: 1.50), frustrated (M: 2.13, SD: 1.30), astonished (M: 2.13, SD: 0.99), worried (M: 2.07, SD: 1.33), annoyed (M: 2.00, SD: 1.13), embarrassed (M: 1.93, SD: 1.16), miserable (M: 1.87, SD: 1.12), depressed (M: 1.73, SD: 1.10), disappointed (M: 1.53, SD: 1.12), offended (M: 1.47, SD: 1.24), ashamed (M: 1.47, SD: 1.06), hurt (M: 1.40, SD: 1.05), and upset (M: 1.33, SD: 1.04); while they felt more or less satisfied (M: 3.13, SD: 1.50), good (M: 3.07, SD: 1.43), proud (M: 2.87, SD: 1.35), and curious (M: 2.87, SD: 1.24) during the flipped classroom based EFL writing course (see Appendix A).

Contrarily, as the findings pointed out the majority of the participants in group B agreed that when they write out-of-class they feel more good (M: 3.93, SD: 0.96), interested (M: 3.60, SD: 1.29), comfortable (M: 3.53, SD: 1.55), motivated (M: 3.53, SD: 1.18), and confident (M: 3.27, SD: 1.28); less satisfied (M: 2.93, SD: 1.10), confused (M: 2.67, SD: 1.34), energetic (M: 2.67, SD: 1.29), bored (M: 2.60, SD: 1.24), thoughtful (M: 2.47, SD: 0.91), puzzled (M: 2.40, SD: 1.24), sleepy (M: 2.33, SD: 1.34), excited (M: 2.33, SD: 1.23), amused (M: 2.33, SD: 1.17), nervous (M: 2.20, SD: 1.32), humiliated (M: 2.20, SD: 1.20), curious (M: 2.20, SD: 1.08), astonished (M: 2.13, SD: 1.06), miserable (M: 2.13, SD: 1.06), tired (M: 2.13, SD: 0.64), frustrated (M: 2.00, SD: 1.36), depressed (M: 1.93, SD: 1.38), indifferent (M: 1.93, SD: 0.70), offended (M: 1.80, SD: 0.86), embarrassed (M: 1.80, SD: 0.77), upset (M: 1.73, SD: 0.88), stressed (M: 1.73, SD: 0.70), ashamed (M: 1.67, SD: 0.90), shy (M: 1.67, SD: 0.72), worried (M: 1.67, SD: 0.72), annoyed (M: 1.60, SD: 0.73), anxious (M: 1.60, SD: 0.63), hurt (M: 1.33, SD: 0.61 ), and disappointed (M: 1.20, SD: 0.41); while they felt more or less relaxed (M: 3.00, SD: 1.41), knowledgeable (M: 3.00, SD: 1.13), proud (M: 2.93, SD: 1.03), neutral (M: 2.80, SD: 1.08), and determined (M: 2.80, SD: 1.01) during the flipped classroom based EFL writing course (see Appendix A).

To sum up, the EFL students had more positive feelings towards the out-of-class flipped classroom model for writing than the in-class flipped classroom model for writing. These findings were different from the findings of the Güvenç (2018) who purposed that EFL learners had more positive feelings towards the in-class writing process, whereas they had negative feelings towards the out-of-class writing process.

Attitudes. Regarding the participants attitudes towards the in-class versus out-of-class flipped classroom models for writing, for the purpose of finding out more detailed information about the EFL students' perceptions towards the flipped classroom models for writing, the participants in group A strongly agreed with the following statements: Both the pre-writing and writing process should be done out of the classroom environment (M: 3.27, SD: 0.79), It is important to have an access to the online resources while writing (M: 3.00, SD: 1.25), I feel that I do not need to hurry up while I write in the classroom (M: 3.00, SD: 1.13), I prefer to get help from my friends (M: 2.90, SD: 0.94), Getting into contact with our class mates for group work is much easier in the classroom environment (M: 2.33, SD: 1.23), I prefer to use online sources when I do not understand something (M: 2.33, SD: 1.23), I cannot concentrate on my writing at particular times of the day (M: 2.07, SD: 1.16), I think it is more effective to write shortly after the pre-writing activities (M: 2.07, SD: 0.88), I prefer to write whenever I want (M: 1.93, SD: 1.28), I can write better when I write without any time limitation (M: 1.87, SD: 1.12), I can understand better what to do when the teacher guides me during the writing process (M: 1.67, SD: 0.91), and Teachers' guidance is necessary for better writing (M: 1.60, SD: 1.12). Similarly, the participants of the group A also agreed with the following statements: Online pre-writing exercises are more enjoyable (M: 3.53, SD: 1.30), I lose my concentration, when I write out of the classroom environment (M: 3.27, SD: 1.38), I feel more concentrated when I write in the classroom environment (M: 2.80, SD: 1.61), I prefer to be taught out of the classroom environment (M: 2.80, SD: 1.32), I write better when I collaborate with my class mates in the classroom environment (M: 1.87, SD: 1.60), I prefer to get help from my instructor (M: 1.87, SD: 0.99), and During the 
in-class writing process we have more chance to get help from the teacher (M: 1.80, SD: 1.14). Significantly majority of the participants revealed that they were neutral about the following statements: During the out-of-class writing process we have more chance to get help from the teacher (M: 3.73, SD: 1.22), Writing outside of the classroom is time consuming (M: 3.47, SD: 1.24), I do not prefer to write out of the classroom environment (M: 3.00, SD: 1.06), I write better when I collaborate with my classmates out of the classroom environment (M: 2.93, SD: 1.16), In class pre-writing exercises are more enjoyable (M: 2.67, SD: 0.72), I feel more concentrated when I write out of the classroom environment (M: 2.47, SD: 1.24), I learn better when I write in the classroom environment (M: 2.20, SD: 1.20), Both the pre-writing and writing process should be done in the classroom environment (M: 2.13, SD: 0.91), I feel that I need to hurry up while I write in the classroom (M: 2.13, SD: 1.35), and I prefer to be taught in the classroom environment (M: 1.87, SD: 1.18). In contrast to these, majority of the participants of the group A disagreed with the following statements: Getting into contact with our class mates for group work is much easier in the online environment (M: 3.80, SD: 0.77), Writing inside the classroom is time consuming (M: 3.27, SD: 1.33), I learn better when I write out of the classroom environment (M: 3.20, SD: 1.01), I lose my concentration, when I write in the classroom environment (M: 3.13, SD: 1.12), and I do not prefer to write in the classroom environment (M: 2.87, SD: 1.24). In particular, majority of the participants were not strongly disagreed with none of the statements about the inclass and out-of-class writing process in a flipped based classroom (see Appendix B).

As the findings pointed out the majority of the participants in group B strongly agreed with the following statements: I lose my concentration, when I write in the classroom environment $(M$ : 2.33, SD: 1.49), I learn better when I write out of the classroom environment (M: 2.20, SD: 1.20), I feel more concentrated when I write out of the classroom environment (M: 1.93, SD: 1.22), It is important to have an access to the online resources while writing (M: 1.93, SD: 1.10), and I can write better when I write without any time limitation (M: 1.67, SD: 0.81). In addition to these, majority of the participants in group B agreed with the following statements: Both the pre-writing and writing process should be done out of the classroom environment (M: 2.87, SD: 1.24), Getting into contact with our class mates for group work is much easier in the online environment (M: 2.53, SD: 1.18), Online pre-writing exercises are more enjoyable (M: 2.47, SD: 0.99), I write better when I collaborate with my classmates out of the classroom environment (M: 2.40, SD: 1.12), Getting into contact with our class mates for group work is much easier in the classroom environment (M: 2.40, SD: 1.05), I feel that I need to hurry up while I write in the classroom (M: 2.40, SD: 0.98), I prefer to be taught in the classroom environment (M: 2.40, SD: 0.91), I prefer to get help from my instructor (M: 2.27, SD: 1.16), Teachers' guidance is necessary for better writing (M: 2.20, SD: 0.67), I prefer to write whenever I want (M: 2.00, SD: 0.75), I think it is more effective to write shortly after the pre-writing activities (M: 1.93, SD: 0.88), I can understand better what to do when the teacher guides me during the writing process (M: 1.93, SD: 0.79), During the in-class writing process we have more chance to get help from the teacher (M: 1.80, SD: 0.77), and I prefer to use online sources when I do not understand something (M: 1.80, SD: 0.60). Particularly, majority of the participants in group B were neutral about the following statements: Writing inside the classroom is time consuming (M: 2.87, SD: 0.64), I prefer to be taught out of the classroom environment (M: 2.67, SD: 0.97), I prefer to get help from friends (M: 2.67, SD: 0.90), I write better when I collaborate with my class mates in the classroom environment (M: 2.67, SD: 0.90), In class pre-writing exercises are more enjoyable (M: 2.47, SD: 0.91 ), I cannot concentrate on my writing at particular times of the day (M: 2.40, SD: 1.16), and Both the pre-writing and writing process should be done in the classroom environment (M: 2.40, SD: 0.98). On the other hand, majority of the participants were disagreed with the following statements: I do not prefer to write out of the classroom environment (M: 4.00, SD: 1.13), I lose my concentration, when I write out of the classroom environment (M: 3.60, SD: 1.24), During the out-of-class writing process we have more chance to get help from the teacher (M: 3.53, SD: 0.99), I feel more concentrated when I write in the classroom environment (M: 3.33, SD: 1.29), I learn better when I write in the classroom environment (M: 3.20, SD: 1.20), and Writing outside of the classroom is time consuming (M: 3.13, SD: 0.91). Further, the participants were also strongly disagreed with the following statement: I feel that I do not need to hurry up while I write in the classroom (M: 4.13, SD: 0.99), I do not prefer to write in the classroom environment (M: 
2.40, SD: 1.18) about the in-class and out-of-class writing process in a flipped based classroom (see Appendix B).

In brief, the findings of the study revealed that EFL students in group A had both a neutral attitude towards the in-class and out-of-class flipped classroom models for writing, while the EFL students in group B had more positive attitudes towards the out-of-class flipped classroom model for writing than the in-class flipped classroom model for writing. These results were contrary with the findings of Kang (2015) who purposed that EFL learners had both positive more positive attitudes towards the in-class writing process, whereas they had both positive and negative attitudes towards the out-of-class writing process. In the same way, the findings were also dissimilar with the findings of the Pavanelli (2018), and Doman and Webb (2016), who agreed that EFL learners had strongly positive attitudes towards the in-class writing process.

\section{Conclusion}

In conclusion, the findings with respect to the primary research question which aimed to examine the most preferred flipped classroom model for writing among in-class versus out-of-class writing models pointed out that the participants in group A preferred to write both in-class and out-ofclass environment, while participants in group B preferred to write only out-of-class environment.

Next, as the second question of the study focused on the EFL studenrts' perceptions towards the in-class versus out-of-class flipped classroom models in the writing process, the researched examined the learners' feelings and attitudes towards the flipped classroom models for writing. According to the findings, both in-class and out-of-class writing has both advantages and disadvantages, and the best source to get help during the in-class writing process is the instructor, while the best source to get help during the out-of-class writing process is the online sources. Afterwards, it was observed that EFL students had more positive feelings towards the out-of-class flipped classroom model for writing than the in-class flipped classroom model for writing, and also the EFL students in group A had both positive and negative attitudes towards the in-class and out-of-class flipped classroom models for writing, while EFL learners in group B had more positive attitudes towards the out-of-class flipped classroom model for writing than the in-class flipped classroom model for writing. To summarize, EFL learners had positive attitudes towards the in-class and out-of-class flipped classroom models for writing however, they had more positive attitudes towards the out-of-class flipped classroom model for writing process.

This investigation is limited to the Turkish Cypriot context and the results of the study might show variances if the context differs. So that, the investigation should not be generalized to the whole contexts. Besides, the investigation is limited to adult EFLstudents and the findings might differ if the study were implemented to different age groups and learners. Moreover, the study is limited with particular number of the participants and the results might differ if the number of participants increase or decrease.

As the data pointed out, the majority of the participants agreed that they prefer to write in both in-class and out-of-class nevertheless, they were in favour of the out-of-class flipped classroom model for writing classes as well as having more positive attitudes towards the out-ofclass flipped classroom model in writing. Accordingly, it is strongly advised that researchers, instructors, educators, syllabus designers, take these findings into consideration, especially in EFL higher education in the Turkish Cypriot context when designing their writing courses based on the flipped classroom approach. Thenceforward, both pre and in-service teachers should use out-of-class flipped classroom models in writing, on account of having an efficient writing classroom in line with their students' needs. Further study might examine the effectiveness of the in-class and out-of-class flipped classroom models in writing classroom, and also the impact of these two models on the EFL students' writing achievement.

\section{References}

Abaeian, H., \& Samadi, L. (2016). The effect of flipped classroom on Iranian EFL learners' L2 reading comprehension: Focusing on different proficiency levels. Journal of Applied Linguistics and Language Research, 3(6), 295-304. 
Abeysekera, L., \& Dawson, P. (2015). Motivation and cognitive load in the flipped classroom: Definition, rationale and a call for research. Higher Education Research and Development, 34(1), 1-14.

Afrilyasanti, R., Cahyono, B. Y., \& Astuti, U. P. (2016). Effect of flipped classroom model on Indonesian EFL students' writing ability across and individual differences in learning. International Journal of English Language and Linguistics Research, 4(5), 66-81.

Agustina, U. W., \& Nur, L. C. (2018). Students positive response on semantic mapping strategy in English writing skill. Journal of English Educators Society, 3(2), 189-196.

Ahmed, D. H., \& Asiksoy, G. (2018). Flipped classroom in language studies: A content analysis of recent articles. Near East University Online Journal of Education, 1(1), 11-19.

Ahmed, M. A. (2016). The effect of a flipping classroom on writing skill in English as a foreign language and students' attitude towards flipping. US-China Foreign Language, 14(2), 98114.

Aidinlou, N. A., Sharefii, S. S., \& Kordabadi, F. S. (2017). Effects of flipped classroom approach on EFL learners' reading performance with different cognitive style. Journal of Applied Linguistics and Language Research, 4(6), 98-104.

Akçayır, G., \& Akçayır, M. (2018). The flipped classroom: A review of its advantages and challenges. Computers and Education, 126, 334-345.

Alastuey , C. B., \& Galar, I. A. (2017). Flipping the EFL classroom in a secondary education setting: Students' perceptions and academic performance. Huarte De San Juan Filología Y Didáctica De La Lengua, 17, 35-57.

Al-Ghamdi, M., \& Al-Bargi, A. (2017). Exploring the application of flipped classrooms on EFL Saudi students' speaking skill. International Journal of Linguistics, 9(4), 28-46.

Al-Shaer, I. M. (2014). Employing concept mapping as a pre-writing strategy to help EFL learners better generate argumentative compositions. International Journal for the Scholarship of Teaching and Learning, 8(2), 1-29.

Alsowat, H. (2016). An EFL flipped classroom teaching model: Effects on English language higher-order thinking skills, student engagement and satisfaction. Journal of Education and Practice, 7(9), 108-121.

Bensen, H., \& Çavuşoğlu, Ç. (2017). Reflections on employing innovative approaches in an academic writing course. Ponte Academic Journal, 73(8). HYPERLINK "http://dx.doi.org/10.21506/j.ponte.2017.8.2" It "_blank" doi: 10.21506/j.ponte.2017.8.2

Carroll, K. (2013, July 10). Writing techniques. Retrieved from WordPress: http://kencarroll.com/2013/07/10/writing-techniques/

Chang, S. Y. (2016). Exploring the efficacy of a flipped EFL basic writing class. Journal of China Scientific Academy, 3(1), 71-94.

Dimililer, Ç., \& Kurt, M. (2019). The impact of collaborative writing and the stream of consciousness technique on writing. Khazar Journal of Humanities and Social Sciences, 22(3), 71-99.

Doman, E., \& Webb, M. (2016). The flipped experience for Chinese university students studying English as a foreign language. TESOL Journal, 8(1), 102-141.

Ekmekci, E. (2017). The flipped writing classroom in Turkish EFL context: A comparative study on a new model. Turkish Online Journal of Distance Education, 18(2), 151-167.

El-Sawy, H. E. (2018). Flipping EFL university classes with blackboard system. English Language Teaching, 11(2), 31-43.

Etikan, I., Musa, S. A., \& Alkassim, R. S. (2016). Comparison of convenience sampling and purposive sampling. American Journal of Theoretical and Applied Statistics, 5(1), 1-4.

Febrijanto, Y. (2016). Promoting mind-mapping technique to improve nursing students' writing skill. Journal of English Teaching and Research, 1(2), 1-14.

Fraga, L. M., \& Harmon, J. (2014). The flipped classroom model of learning in higher education: An investigation of preservice teachers' perspectives and achievement. Journal of Digital Learning in Teacher Education, 31(1), 18-27.

Ghalib, T. K., \& Al-Hattami, A. A. (2015). Holistic versus analytic evaluation of EFL writing: A case study . English Language Teaching, 8(7), 225-236. 
Green, A. C. (2015). Approaches to mixed methods dissemination and implementation research: Methods, strengths, caveats, and opportunities. Adm Policy Ment Health, 42(5), 508-523.

Güvenç, G. (2018). The flipped classroom approach in teaching writing: An action research. International Journal of Social Sciences and Education Research, 4(3), 421-432.

Helgeson, J. (2015). Flipping the English classroom. Kappa Delta Pi Record, 51(2), 64-68.

Hinrichs, P. (2011). When the bell tolls: The effects of school starting times on academic achievement. Association for Education Finance and Policy, 486-508.

Hsiao, C. C., Huang, J. C., Huang, A. Y., Lu, O. H., Yin, C. J., \& Yang, S. J. (2018). Exploring the effects of online learning behaviors on short-term and long-term learning outcomes in flipped classrooms. Interactive Learning Environments, 1-17.

Hung, H. T. (2015). Flipping the classroom for English language learners to foster active learning. Computer Assisted Language Learning, 28(1), 81-96.

Ibnian, S. S. (2010). The effect of using the story mapping technique on developing tenth grade students' short story writing skills in EFL. English Language Teaching, 3(4), 181-194.

Kang, N. (2015). The comparison between regular and flipped classrooms for EFL Korean adult learners. Multimedia-Assisted Language Learning 18(3), 41-72.

Kim, D. (2017). Flipped interpreting classroom: flipping approaches, student perceptions and design considerations. The Interpreter and Translator Trainer, 11(1), 38-55.

Koura, A. A., \& Zahran, F. A. (2017). Using habits of mind to develop EFL writing skills and autonomy. Arab World English Journal, 8(4), 183-198.

Lin, C. J., \& Hwang, G. J. (2018). A flipped classroom approach to supporting game based learning activities for EFL business writing course. 3rd Annual International Seminar on Transformative Education and Educational Leadership (pp. 151-155). Advances in Social Science Education and Humanities Research.

Little, C. (2015). The flipped classroom in further education: literature review and case study. Research in Post-Compulsory Education, 20(3), 265-279.

Mahnam, L., \& Nejadansari, D. (2012). The effects of different pre-writing strategies on Iranian EFL writing achievement . International Education Studies, 5(1), 154-160.

Mehring, J. (2016). Present research on the flipped classroom and potential tools for the EFL classroom. Computers in the Schools Interdisciplinary Journal of Practice, Theory, and Applied Research, 33(1), 1-10.

Ningrum, A. S., Latief, M. A., \& Sulistyo, G. H. (2016). The effect of mind mapping on EFL students' idea development in argumentative writing across gender differences and learning styles. Dinamika Ilmu, 16(1), 149-166.

BIBLIOGRAPHY Odoh, M., \& Chinedum, I. (2014). Research designs, survey and case study. IOSR Journal of VLSI and Signal Processing, 4(6), 16-22.

Panopto. (2017, May 26). 7 Unique flipped classroom models: Which is right for you? Retrieved from Panopto: https://www.panopto.com/blog/7-unique-flipped-classroom-models-right/

Pavanelli, R. (2018). The flipped classroom: A mixed methods study of academic performance and student perception in EAP writing context. International Journal of Language and Linguistics, 5(2), 16-26.

Pope, N. G. (2016). How the time of day affects productivity: Evidence from school schedules. The Review of Economics and Statistics, 98(1), 1-11.

Qader, R. O., \& Arslan, F. Y. (2019). The effect of flipped classroom instruction in writing: A case study with Iraq1 EFL learners. Teaching English with Technology, 19(1), 36-55.

Sage, M., \& Sele, P. (2015). Reflective journaling as a flipped classroom technique to increase reading and participation with social work students. Journal of Social Work Education, 51(4), 668-681.

Salem, A. A. (2018). Engaging ESP university students in flipped classrooms for developing functional writing skills, HOTs, and eliminating writer's block. Published by Canadian Center of Science and Education, 11(12), 177-198.

Santikarn, B., \& Wichadee, S. (2018). Flipping the classroom for English language learners: A study of learning performance and perceptions. International Journal of Emerging Technologies in Learning, 13(9), 123-135. 
Santosa, M. H. (2017). Learning approaches of Indonesian EFL Gen Z students in a flipped learning context. Journal on English as a Foreign Language, 7(2), 183-208.

Saunders, M., Lewis, P., \& Thornhill, A. (2012). Research methods for business students (6th ed.). Harlow: Pearson Education.

Shapiro, T. M. (2015). The educational effects of school start times. IZA World of Labor, 1-10.

Shapiro, T. M., \& Williams, K. M. (2014, March 29). The causal effect of the school day schedule on the academic achievement of adolescents. Retrieved from Sole Jole: http://www.solejole.org/15145.pdf

Site, E. W. (2018). Writing techniques for essays. Retrieved from Essaywritersite.com: https://essaywritersite.com/writing-tips

Soltanpour, F., \& Valizadeh, M. (2017). A flipped writing classroom: Effects on EFL learners' argumentative essays. Advances in Language and Literary Studies, 9(1), 5-13.

Suwanthep, S. L. (2017). Integration of flipped classroom model for EFL speaking. International Journal of Learning and Teaching, 3(2), 118-123.

Suyanto, A. (2015). The effectiveness of mindmapping in improving students' writing skill viewed from their IQ. Indonesian Journal of English Education, 2(2), 101-119.

Şengül, F. (2018). Indirect written corrective feedback in English as a foreign language classes (master's thesis). Near East University, Nicosia, North Cyprus.

Thakare, R. (2018, July 25). 8 Types of flipped learning classrooms and tools to build them. Retrieved from E-Learning Industry: https://elearningindustry.com/flipped-learningclassrooms-tools-build-types

Turgut, F., \& Kayaoğlu, M. N. (2015). Using rubrics as an instructional tool in EFL writing courses. Journal of Language and Linguistic Studies, 11(1), 47-58.

Ügüten, S. D., \& Balc1, Ö. (2017). Flipped learning. Journal of Süleyman Demirel University Institute of Social Sciences, 1(26), 253-265.

Vijayavalsalan, B., \& Dhabi, A. (2016). Mind Mapping as a strategy for enhancing essay writing skills. The New Educational Review, 137-148.

Virginia, U. O. (2015, November 16). Using and interpreting cronbach's alpha. Retrieved from University of Virginia Library: https://data.library.virginia.edu/using-and-interpretingcronbachs-alpha/

Wang, S., \& Liu, C. (2018). Task-based flipped classroom in Chinese college EFL teaching: An empirical study in oral English course. International Journal of Contemporary Education, $1(1), 12-18$.

Zou, D., \& Xie, H. (2018). Flipping an English writing class with technology enhanced just in time teaching and peer instruction. Interactive Learning Environments, 1-16. 